\title{
Pronounced skin capillary ischemia in the feet of diabetic patients with bad metabolic control
}

\author{
G.Jörneskog ${ }^{1,2}$, K. Brismar ${ }^{2}$, B. Fagrell ${ }^{1}$ \\ ${ }^{1}$ Department of Internal Medicine, Karolinska Hospital, Stockholm, Sweden \\ ${ }^{2}$ Department of Endocrinology and Diabetology, Karolinska Hospital, Stockholm, Sweden
}

\begin{abstract}
Summary Skin capillary circulation is impaired during postocclusive reactive hyperaemia (PRH) in toes of diabetic patients independent of diabetes duration and macrocirculation. The aim of this study was to examine its relation to metabolic control. The skin microcirculation was investigated in 20 patients with insulin-dependent diabetes mellitus: 10 patients with bad $\left[\mathrm{HbA}_{1 \mathrm{c}}>7.5(8.7 \pm 0.8) \%\right]$, and 10 patients with good metabolic control $\left[\mathrm{HbA}_{1 \mathrm{c}}<7.5(6.3 \pm 1.0) \%\right]$. The diabetes duration was similar in both groups (16 \pm 9 and $16 \pm 6$ years, respectively). None had macroangiopathy. Thirteen healthy subjects served as controls. The capillary blood cell velocity (CBV) in the nailfold of the great toe was investigated by videophotometric capillaroscopy, and the total skin microcirculation by laser Doppler fluxmetry (LDF). CBV and LDF were studied during rest and after 1min arterial occlusion. The vibration perception thresholds (VPT) of the feet were higher $(p<0.05)$ in the patients with bad $(34 \pm 12 \mathrm{~V})$, as compared to
\end{abstract}

patients with good metabolic control $(18 \pm 10 \mathrm{~V})$ and to healthy subjects $(13 \pm 3 \mathrm{~V})$. Peak CBV during PRH was reduced in both patient groups $(p<0.01)$, and lowest in the patients with bad metabolic control $(p<0.05)$. Time to peak CBV was prolonged $(p<0.01)$ in the patients with bad, while normal in the patients with good metabolic control. LDF was similar in all groups. An inverse correlation was found between $\mathrm{HbA}_{1 \mathrm{c}}$ and peak $\mathrm{CBV}$ during $\mathrm{PRH}$ $(r=0.60 ; p=0.008)$, while positive correlations were found to time to peak CBV $(r=0.62 ; p=0.004)$ and VPT $(r=0.60 ; p=0.01)$. No associations were seen between VPT and the microcirculatory variables. The results indicate that the metabolic control is of importance for the nutritive capillary circulation and the peripheral nerve function in the diabetic foot. [Diabetologia (1998) 41: 410-415]

Keywords Diabetes mellitus, skin capillary circulation, metabolic control
An impaired skin capillary circulation has been demonstrated in the diabetic foot during postocclusive reactive hyperaemia (PRH), and this "capillary ischaemia" was independent of diabetes duration and was shown despite normal macrocirculation $[1,2]$. The re-

\section{Received: 22 October 1997}

Corresponding author: Gun Jörneskog, M.D., PhD., Department of Internal Medicine, Karolinska Hospital, S-17176 Stockholm, Sweden

Abbreviations: CBV, capillary blood cell velocity; LDF, laser Doppler fluxmetry; PRH, postocclusive reactive hyperaemia; VPT, vibration perception threshold; PVD, peripheral vascular disease. duction of maximal blood flow in the nutritional skin capillaries is more pronounced when late diabetic complications are present [1-3], but can already be shown early after diabetes onset $[1,2]$, suggesting that functional disturbances in skin microcirculation precede late diabetic complications. The microcirculatory findings indicate that there is a maldistribution of blood between nutritive capillaries and subpapillary vessels leading to reduced blood flow in the capillaries. This maldistribution may be one factor leading to impaired tissue oxygenation in diabetes $[4,5]$. As the feet are a region exposed to great stress, a disturbed circulation in nutritional capillaries may generate a regional ischaemia contributing to complications such as neuropathy and chronic foot ulcers $[6$, 
7]. The exact mechanism behind the maldistribution of blood between nutritional and non-nutritional microvessels is not fully known, but the metabolic control may be of importance since hyperglycaemia causes functional endothelial disturbances [8-12] which may progress to structural changes $[13,14]$.

The aim of the present study was to investigate the skin microvascular reactivity in two groups of insulindependent diabetic patients, one with "good" and one with "bad" metabolic control, to see if any differences in functional microangiopathy could be related to the degree of metabolic control.

\section{Subjects and methods}

Patients. Two groups of patients with insulin-dependent diabetes mellitus (IDDM), one with good $\left[\mathrm{HbA}_{1 \mathrm{c}}<7.5\right.$ $(6.3 \pm 1.0) \%]$ and one with bad $\left[\mathrm{HbA}_{1 \mathrm{c}}>7.5(8.7 \pm 0.8) \%\right]$ metabolic control $(p<0.001)$, were investigated. The reference value for $\mathrm{HbA}_{1 \mathrm{c}}$ was $<5.5 \%$. Clinical data are presented in Table 1. The patient groups were similar in age and diabetes duration. None of the patients had any history of cerebral or cardiovascular events or clinical signs of peripheral vascular disease (PVD) as evaluated by segmental blood pressure measurements [15] (Table 2). One patient, with good metabolic control, had a high ankle blood pressure $(250 \mathrm{~mm} \mathrm{Hg})$, indicating increased calcification of the vessel walls in the lower extremities. Peripheral neuropathy was assessed by measuring vibration perception thresholds of the feet by biothesiometry [16, 17] (Bio-Medical Instrument Company, Newbury, Ohio, USA) (Table 2). Urine was collected in overnight samples for determination of microalbuminuria [18], and the eyes were examined by an ophthalmologist with ophthalmoscopy and fundus photography. All patients were treated with four doses of insulin daily. Regular insulin was given with meals and NPH at night.

Healthy control subjects. Thirteen healthy subjects similar in age to the patients were investigated. None of the healthy subjects had any family history of diabetes and the $\mathrm{HbA}_{1 \mathrm{c}}$-value was $3.7 \pm 0.5 \%$.

Methods. The skin microcirculation in the nailfold of the great toe was investigated by computerised videophotometric capillaroscopy [19-22] and laser Doppler fluxmetry [22, 23]. The investigations were performed in the morning approximately 60 min after breakfast and 90 min after injection of regular insulin. All subjects were acclimatized for $30 \mathrm{~min}$ before the investigations started, and the room temperature was kept between 22 and $24^{\circ} \mathrm{C}$. All participants were asked to refrain from smoking and drinking coffee $8 \mathrm{~h}$ before the study. The subjects were investigated in the supine position with the knees slightly flexed and the feet at the heart level. The legs were resting comfortably in a special holder to avoid involuntary movements of the feet. A miniature cuff ( $20 \mathrm{~mm}$ wide) was applied at the proximal phalanx of the investigated great toe so that arterial occlusions could be performed. The skin temperature of the toe nailfold was continuously recorded with an electronic thermistor (Exacon, Copenhagen, Denmark).

Videophotometric capillaroscopy. Nailfold capillaries of the great toe were visualized on a TV-monitor by a Leitz Laborlux microscope [Leica (Leitz), Wetzlar, Germany] on which a
Table 1. Clinical details of the diabetic patients and healthy control subjects

\begin{tabular}{|c|c|c|c|}
\hline & $\begin{array}{l}\text { Good } \\
\text { Metabolic } \\
\text { Control }\end{array}$ & $\begin{array}{l}\text { Bad } \\
\text { Metabolic } \\
\text { Control }\end{array}$ & $\begin{array}{l}\text { Healthy } \\
\text { Subjects }\end{array}$ \\
\hline $\mathrm{HbA}_{1 \mathrm{c}}(\%)$ & $6.3 \pm 1.0$ & $8.7 \pm 0.8^{\mathrm{a}}$ & $3.7 \pm 0.5^{\mathrm{b}}$ \\
\hline Sex (female: male) & $3: 7$ & $5: 5$ & $5: 8$ \\
\hline Age (years) & $35 \pm 7$ & $42 \pm 12$ & $41 \pm 12$ \\
\hline Smokers (n) & 4 & 5 & 3 \\
\hline $\begin{array}{l}\text { Duration of } \\
\text { diabetes (years) }\end{array}$ & $16 \pm 6$ & $16 \pm 9$ & - \\
\hline $\begin{array}{l}\text { Retinopathy } \\
\text { (Background/preprolif) }\end{array}$ & $8 / 2$ & $5 / 5$ & - \\
\hline Microalbuminuria (n) & 6 & 7 & - \\
\hline
\end{tabular}

Results expressed as number (n), or mean \pm SD

${ }^{a} p<0.001$ as compared to patients with good metabolic control

${ }^{\mathrm{b}} p=0.0001$ as compared to diabetic patients

Table 2. Vibration perception thresholds and peripheral blood pressure measurements in diabetic patients and healthy control subjects

\begin{tabular}{llll}
\hline & $\begin{array}{l}\text { Good } \\
\text { Metabolic } \\
\text { Control }\end{array}$ & $\begin{array}{l}\text { Bad } \\
\text { Metabolic } \\
\text { Control }\end{array}$ & $\begin{array}{l}\text { Healthy } \\
\text { Subjects }\end{array}$ \\
\hline $\mathrm{n}$ & 10 & 10 & 13 \\
$\begin{array}{l}\text { Vibration } \\
\text { perception } \\
\text { threshold (V) }\end{array}$ & $18 \pm 10$ & $34 \pm 12^{\mathrm{a}}$ & $13 \pm 3$ \\
$\begin{array}{l}\text { Arm blood } \\
\text { pressure } \\
\text { (mm Hg) }\end{array}$ & $125 \pm 13 / 80 \pm 11$ & $134 \pm 15 / 82 \pm 9$ & $128 \pm 15 / 80 \pm 10$ \\
$\begin{array}{l}\text { Ankle blood } \\
\text { pressure } \\
\text { (mm Hg) }\end{array}$ & $148 \pm 41$ & $133 \pm 19$ & $135 \pm 20$ \\
$\begin{array}{l}\text { Toe blood } \\
\text { pressure } \\
\text { (mm Hg) }\end{array}$ & $121 \pm 22$ & $115 \pm 16$ & $120 \pm 20$ \\
$\begin{array}{l}\text { Toe/arm } \\
\text { blood } \\
\text { pressure } \\
\text { index }\end{array}$ & $1.0 \pm 0.2$ & $0.9 \pm 0.2$ & $0.9 \pm 0.1$ \\
\hline
\end{tabular}

Values expressed as mean $\pm \mathrm{SD}$

${ }^{\mathrm{a}} p<0.05$ as compared to patients with good metabolic control and to healthy controls

CCD video camera (ICD-44 DC, Ikegami, Tokyo, Japan) was mounted. The image was stored on videotape for subsequent analysis. The capillary blood cell velocity (CBV) was determined by a computerised, videophotometric, cross-correlation technique [19-22] (Capiflow AB, Stockholm, Sweden). CBV was measured in a suitable capillary with good contrast and visible signals. This has been shown to be relevant for studying skin microvascular reactivity [24, 25]. The following variables were determined: $\mathrm{CBV}$ was continuously computed for $3 \mathrm{~min}$ and the computer-integrated mean value during this period is termed resting CBV $(\mathrm{mm} / \mathrm{s})$; peak $\mathrm{CBV}(\mathrm{mm} / \mathrm{s})$, time to peak $\mathrm{CBV}(\mathrm{s})$, and per cent increase of resting CBV (CBV\%) were measured following release of a $1 \mathrm{~min}$ arterial occlusion at the 
Table 3. Microcirculatory data in the diabetic patients and healthy controls

\begin{tabular}{lclc}
\hline & $\begin{array}{l}\text { Good } \\
\text { Metabolic } \\
\text { Control }\end{array}$ & $\begin{array}{l}\text { Bad } \\
\text { Metabolic } \\
\text { Control }\end{array}$ & $\begin{array}{l}\text { Healthy } \\
\text { Subjects }\end{array}$ \\
\hline $\mathrm{n}$ & 10 & 10 & 13 \\
Skin temperature $\left({ }^{\circ} \mathrm{C}\right)$ & $29.5 \pm 1.8$ & $28.1 \pm 1.6^{\mathrm{d}}$ & $28.9 \pm 2.1$ \\
Resting CBV (mm/s) & $0.24 \pm 0.28$ & $0.12 \pm 0.11^{\mathrm{a}}$ & $0.34 \pm 0.38$ \\
Peak CBV (mm/s) & $0.24 \pm 0.23^{\mathrm{b}}$ & $0.10 \pm 0.06^{\mathrm{c}, \mathrm{d}}$ & $0.58 \pm 0.32$ \\
Time to peak CBV (s) & $12.8 \pm 4.4^{\mathrm{b}}$ & $36.2 \pm 21.6^{\mathrm{b}, \mathrm{e}}$ & $14.8 \pm 5.7$ \\
CBV\% & $40 \pm 103^{\mathrm{b}}$ & $2 \pm 35^{\mathrm{c}}$ & $137 \pm 111$ \\
Resting LDF (V) & $2.0 \pm 1.4$ & $2.3 \pm 2.5$ & $1.2 \pm 0.8$ \\
Peak LDF (V) & $3.2 \pm 1.9$ & $2.9 \pm 2.8$ & $2.7 \pm 1.3$ \\
Time to peak LDF (s) & $8.0 \pm 2.8$ & $11.8 \pm 6.0$ & $8.5 \pm 3.8$ \\
LDF\% & $155 \pm 210$ & $66 \pm 78^{\mathrm{a}}$ & $185 \pm 119$ \\
Biological zero (V) & $0.21 \pm 0.15$ & $0.11 \pm 0.07$ & $0.19 \pm 0.11$ \\
Resting CBV/LDF & $0.19 \pm 0.15$ & $0.09 \pm 0.11^{\mathrm{b}}$ & $0.38 \pm 0.38$ \\
Peak CBV/LDF & $0.09 \pm 0.06^{\mathrm{b}}$ & $0.06 \pm 0.05^{\mathrm{c}}$ & $0.24 \pm 0.14$ \\
\hline CBV capillary blood & &
\end{tabular}

$\mathrm{CBV}=$ capillary blood cell velocity. $\mathrm{LDF}=$ laser Doppler fluxmetry. Values are given as mean \pm SD.

${ }^{\mathrm{a}} p<0.05,{ }^{\mathrm{b}} p<0.01,{ }^{\mathrm{c}} p<0.001$ as compared to healthy controls.

${ }^{\mathrm{d}} p<0.05$, ${ }^{\mathrm{e}} p<0.01$ as compared to patients with good metabolic control

proximal phalanx of the toe with a cuff pressure of $200 \mathrm{~mm} \mathrm{Hg}$. The reproducibility of the capillaroscopic technique used has been tested in earlier studies [1, 2, 25, 26].

In a separate study, the influence of leg position on skin capillary circulation in the toes was investigated in five healthy subjects. Resting CBV in nailfold capillaries was measured a) when the knees were slightly flexed, and then b) when the legs were in the straight position. The investigations were performed with the subject in the supine position and with the feet at the heart level. The same capillaries were investigated in the two positions. The results show no differences in resting CBV between the two positions: knees slightly flexed $0.12 \pm 0.08(\min 0.04 ; \max 0.23) \mathrm{mm} / \mathrm{s}$ compared to knees straight $0.12 \pm 0.07(\min 0.06 ; \max 0.22) \mathrm{mm} / \mathrm{s}$. Resting CBV was measured for 1 to $3 \mathrm{~min}$ in each position.

Laser Doppler Fluxmetry. The total skin microcirculation was measured by laser Doppler fluxmetry (LDF) (Periflux, Pf 1d, Perimed, Stockholm, Sweden) simultaneously with videophotometric capillaroscopy [22]. The laser Doppler output signal, which to more than $90 \%$ is generated by flow in subpapillary vessels [23], was continuously registered on a pen recorder and the full scale deflection was $10 \mathrm{~V}$. A band-width of $4 \mathrm{Khz}$ and a gain of 10 times were used. The laser Doppler probe was placed within the skin area immediately adjacent to the microscopic field of view and LDF was measured continuously. The following variables were measured: LDF was calculated at $5 \mathrm{~s}$ intervals for 3 min and the mean LDF for this period was termed resting $\operatorname{LDF}(\mathrm{V})$. Peak LDF (V), time to peak LDF (s), and per cent increase of resting LDF (LDF\%) were measured after a 1-min arterial occlusion at the proximal phalanx of the toe. The remaining flux signal during the arterial occlusion was considered to be the biological zero $(\mathrm{V})$ value, which was subtracted from the total laser Doppler signal $[23,27]$. The ratios between CBV and LDF during rest and postocclusive reactive hyperaemia, respectively, were calculated. This ratio represents an index for the distribution of blood between capillary and subpapillary vessels.
Laboratory Tests. Venous blood was taken for determination of glycosylated haemoglobin $\left(\mathrm{HbA}_{1 \mathrm{c}}\right)$. $\mathrm{HbA}_{1 \mathrm{c}}$ was analysed by the ELISA-method using monoclonal antibodies (Dakopatts, DAKO Diagnostics Ltd, Cambridge, UK). Microalbuminuria was determined by a nephelometric assay (Array, Beckman Instruments Inc., Brea, Calif., USA).

Statistical analysis. Data are given as mean \pm SD. The MannWhitney U test and Kruskal Wallis test were used to test differences between the groups. A value of $p<0.05$ was considered statistically significant. The relationship between microcirculatory and other variables were investigated with simple regression analysis.

Ethical considerations. All subjects gave their informed consent to the study. The study was approved by the ethics committee of the Karolinska Hospital.

\section{Results}

The microcirculatory data are shown in Table 3 . The skin temperature, resting $\mathrm{LDF}$, peak LDF, time to peak LDF, and biological zero were similar in patients and healthy control subjects. A somewhat lower $(p<0.05)$ skin temperature was seen in the patients with bad metabolic control, as compared to the patients with good metabolic control.

Resting CBV was reduced $(p<0.05)$ in the patients with bad metabolic control, as compared to healthy control subjects, while it was similar to patients with good metabolic control.

Peak CBV was decreased $(p<0.01)$ in both diabetic groups, as compared to healthy subjects. However, the patients with bad metabolic control had lower peak CBV $(p=0.02)$ than the patients with good metabolic control (Fig.1). Time to peak CBV was prolonged $(p<0.01)$ in the patients with bad metabolic control, both as compared to healthy subjects and to patients with good metabolic control, while the patients with good metabolic control showed values similar to healthy control subjects (Fig.2). CBV\% was lower $(p<0.01)$ in both patient groups, as compared to healthy control subjects, while LDF \% was decreased $(p<0.05)$ in the patients with bad metabolic control.

The ratio between resting $\mathrm{CBV}$ and resting LDF was reduced $(p<0.01)$ in the patients with bad metabolic control, while the ratio between peak CBV and peak LDF was decreased $(p<0.01)$ in both patient groups, as compared to healthy control subjects. No significant differences were seen between the patient groups regarding these two variables. An inverse correlation $(r=-0.60 ; p=0.008)$ was seen between the metabolic control $\left(\mathrm{HbA}_{1 \mathrm{c}}\right)$ and peak CBV (Fig. 3), while a positive correlation $(r=0.62 ; p=0.004)$ was found between $\mathrm{HbA}_{1 \mathrm{c}}$ and time to peak CBV (Fig. 4).

The diabetic patients with bad metabolic control had higher $(p<0.05)$ vibration perception thresholds than the patients with good metabolic control and 


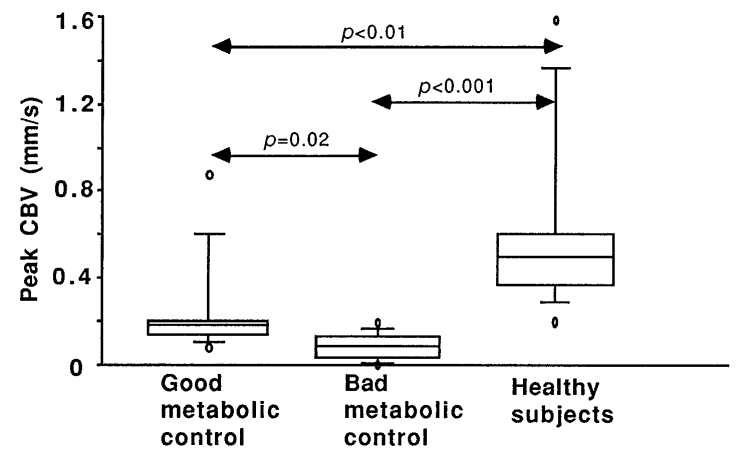

Fig. 1. Peak capillary blood cell velocity (CBV) in 10 patients with good metabolic control, 10 patients with bad metabolic control, and in 13 healthy control subjects. Box-plot values of peak CBV showing median values and the 10th, 25th, 75th and 90th percentiles

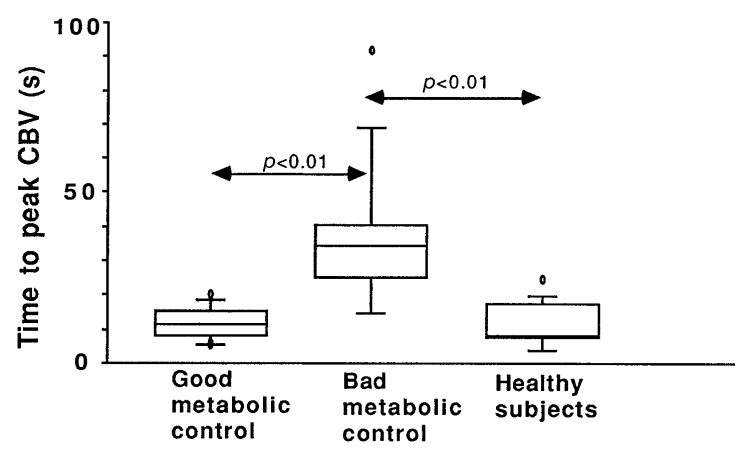

Fig. 2. Time to peak capillary blood cell velocity (CBV) in 10 patients with good metabolic control, 10 patients with bad metabolic control, and in 13 healthy control subjects. Boxplot values of peak CBV showing median values and the 10th, 25 th, 75 th and 90 th percentiles

healthy control subjects (Table 2). A positive correlation was found between $\mathrm{HbA}_{1 \mathrm{c}}$ and the vibration perception threshold (VPT) $(r=0.60 ; p=0.01)$ in the patients (Fig.5), while no significant correlations were found between the VPT and the microcirculatory variables, i.e. peak CBV $(r=-0.36 ; p=0.12)$, time to peak $\mathrm{CBV}(r=0.32 ; p=0.17)$ and $\mathrm{CBV} \%$ $(r=-0.27 ; p=0.26)$.

\section{Discussion}

The results of the present study show an impaired skin capillary circulation in the feet of diabetic patients, despite normal macrocirculation and total skin microcirculation. However, the results also show a more pronounced "capillary ischaemia" in the patients with bad metabolic control, defined as $\mathrm{HbA}_{1 \mathrm{c}}>7.5 \%$, which is in agreement with other studies showing an association between metabolic control and the development of late diabetic complications [14]. In the present study, the patients with

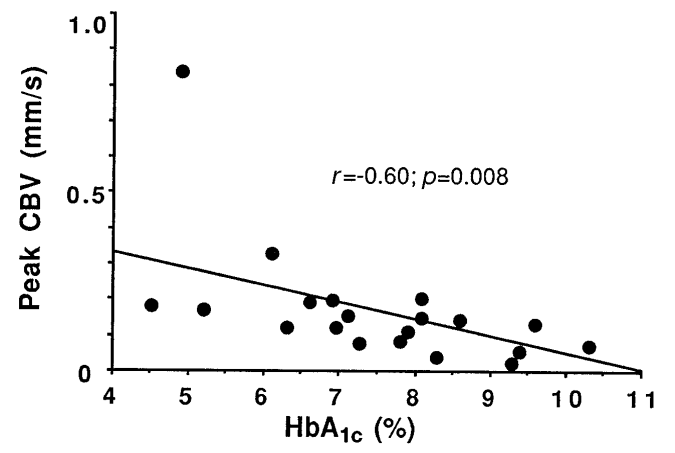

Fig. 3. Relation between $\mathrm{HbA}_{1 \mathrm{c}}$ and peak capillary blood cell velocity $(\mathrm{CBV})$ in 20 patients with IDDM

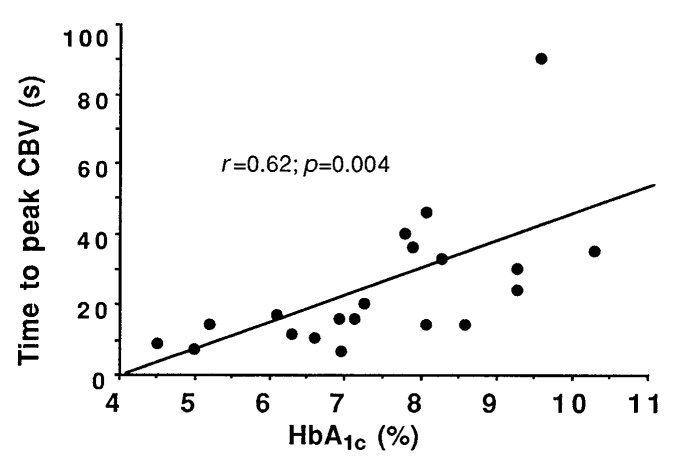

Fig. 4. Relation between $\mathrm{HbA}_{1 \mathrm{c}}$ and time to peak capillary blood cell velocity (CBV) in 20 patients with IDDM

bad metabolic control showed a lower and more delayed response in the capillaries during postocclusive reactive hyperaemia (PRH), as compared to corresponding patients with good metabolic control $\left(\mathrm{HbA}_{1 \mathrm{c}}<7.5 \%\right)$. These differences in skin microvascular reactivity between the two patient groups were demonstrated despite similar age, diabetes duration, peripheral blood pressures and total skin microcirculation. A slightly lower $(p=0.04)$ skin temperature in the patients with bad metabolic control may contribute to the reduced CBV in these patients, especially during resting conditions.

The reduced capillary circulation during PRH may be due to an impaired ability to dilate precapillary vessels $[28,29]$. During arterial occlusion the intravascular pressure distal to the pressure cuff falls to almost zero. This causes a decrease in myogenic vascular tones, which, on release of cuff pressure, leads to a rapid increase in blood flow to the area [30-33]. Several factors are most probably involved in the impaired vasodilatory capacity seen in diabetic patients. One factor might be an increased stiffness in precapillary vessel walls due to increased glycosylation and formation of non-enzymatic advanced glycosylation end-products. These compounds are formed slowly through chemically irreversible processes and accumulate continuously with time, and may contribute to diabetic angiopathy [34]. Biochemical changes 


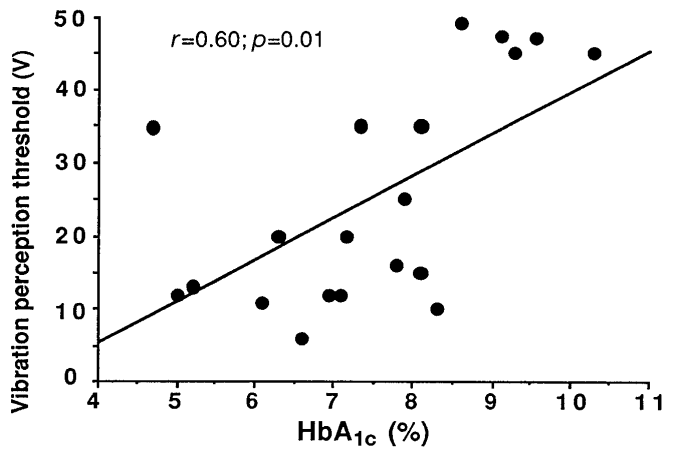

Fig. 5. Relation between $\mathrm{HbA}_{1 \mathrm{c}}$ and vibration perception threshold in 20 patients with IDDM

contribute also to changes in the vascular basement membrane. The capillary basement membrane is thicker in diabetic patients and this alteration is more pronounced in the legs, most likely due to the higher hydrostatic pressure in this part of the body [35]. However, the metabolic control seems also to be important [36]. A thick basement membrane may decrease the elastic properties of the vessel walls and reduce PRH. Endothelial cellular dysfunction is another factor which most probably influences local microvascular regulation, as the endothelial production of locally vasoactive substances, such as nitric oxide and prostanoids, may be altered [37-39].

Functional and structural changes in skin microcirculation may force blood from nutritional capillaries to subpapillary vessels with lower resistance, e.g. arteriovenous (AV) connections [40]. These AV-shunts are innervated by sympathetic nerves [41], and consequently denervation, as in our patients with severe neuropathy, may lead to an opening of these shunts and a further maldistribution of blood between capillaries and subpapillary vessels. In the present study no significant associations were found between peripheral sensory neuropathy, as evaluated by VPT, and the microcirculatory variables. This may be due to the rather small sample size in the study. However, another explanation for the lack of correlation to VPT may be that disturbances in peripheral autonomic nerve function precede and are independent of sensory nerve function. We have shown earlier that the skin capillary ischemia in the diabetic foot can be demonstrated very early after onset of diabetes $[1,2]$ and in patients without any evidence of complications, which supports our postulation that this microvascular disturbance may in the long run contribute to the development of late diabetic complications, e.g. neuropathy. An increased arteriovenous shunting has also been demonstrated in the vasa nervorum of the sural nerve [7], leading to impaired oxygenation of the nerve and probably sensory dysfunction. It has been suggested that hyperglycaemia induces a relative intracellular hypoxia (pseudohypoxia), which provides an explanation for the increased susceptibility of diabetic patients to hypoxic and ischaemic injury [42]. "Capillary ischaemia" due to functional disturbances in microcirculation may be another factor causing impaired tissue oxygenation in diabetic patients [5].

In conclusion, the results of the present study indicate that metabolic control is of importance for skin capillary circulation in the diabetic foot. The microvascular disturbance is characterised by a maldistribution of blood from nutritive skin capillaries to subpapillary vessels leading to capillary ischemia. These disturbances in nutritive microcirculation may be of importance for the development of diabetic foot complications and may explain why the diabetic foot is more susceptible to pressure and has an impaired ulcer healing process.

Acknowledgements. This work was supported by grants from Swedish Medical Research Council (Grant 6835), Swedish Society of Medicine, Swedish Society for Medical Research, Swedish Heart Lung Foundation, Swedish Diabetes Association, and Karolinska Institute.

The authors wish to thank Mrs Ann-Christin Salomonsson for excellent technical assistance in this study.

\section{References}

1. Jörneskog G, Brismar K, Fagrell B (1995) Skin capillary circulation severely impaired in toes of patients with IDDM, with and without late diabetic complications. Diabetologia 38: 474-480

2. Jörneskog G (1995) Functional microangiopathy in the digital skin of patients with diabetes mellitus. Thesis. Stockholm

3. Jörneskog G, Brismar K, Fagrell B (1995) Skin capillary circulation is more impaired in toes of diabetic than non-diabetic patients with peripheral vascular disease. Diabet Med 12: 36-41

4. Ditzel J (1975) The problem of tissue oxygenation in diabetes mellitus. Acta med Scand [Suppl] 578: 49-68

5. Tuck RR, Schmelzer JD, Low PA (1984) Endoneurial blood flow and oxygen tension in the sciatic nerves of rats with experimental diabetic neuropathy. Brain 107: 935-950

6. Edmonds ME, Watkins PJ (1992) The diabetic foot. In: Alberti KGMM, DeFronzo RA, Keen H, Zimmet P (eds) International textbook of diabetes mellitus, Vol2. Wiley, Chichester, pp 1535-1549

7. Tesfaye S, Malik R, Ward JD (1994) Vascular factors in diabetic neuropathy. Diabetologia 37: 847-854

8. Gundersen HJG (1974) Peripheral blood flow and metabolic control in juvenile diabetes. Diabetologia 10: 225-231

9. Rayman G, Williams S, Hassan A, Gamble J, Tooke JE (1985) Capillary hypertension and overperfusion in the feet of young diabetics. Diabet Med 2: 304

10. Jaap AJ, Shore AC, Gartside IB, Gamble J, Tooke JE (1993) Increased microvascular fluid permeability in young type 1 (insulin-dependent) diabetic patients. Diabetologia 36: 648-652

11. Porta M, La Selva M, Molinatti P, Molinatti GM (1987) Endothelial cell function in diabetic microangiopathy. Diabetologia 30: 601-609

12. Sandeman DD, Shore AC, Tooke JE (1992) Relation of skin capillary pressure in patients with insulin-dependent 
diabetes mellitus to complications and metabolic control. $\mathrm{N}$ Engl J Med 327: 760-764

13. Williamson JR, Kilo C (1977) Current status of capillary basement-membrane disease in diabetes mellitus. Diabetes 26: $65-73$

14. Diabetes Control and Complications Trial Research Group (1993) The effect of intensive treatment of diabetes on the development and progression of long-term complications in insulin-dependent diabetes mellitus. N Engl J Med 329: 977-986

15. Gundersen J (1972) Segmental measurements of systolic blood pressure in the extremities including the thumb and the great toe. Acta Chir Scand [Suppl] 426: 51-65

16. Guy RJC, Clark CA, Malcolm PN, Watkins PJ (1985) Evaluation of thermal and vibration sensation in diabetic neuropathy. Diabetologia 28: 131-137

17. Bloom S, Till S, Sonksen P, Smith S (1984) Use of biothesiometer to measure individual vibration thresholds and their variation in 519 non-diabetic subjects. BMJ 288: 1793-1795

18. Rowe DJF, Dawnay A, Watts GF (1990) Microalbuminuria in diabetes mellitus: review and recommendations for the measurements of albumin in urine. Ann Clin Biochem 27: 297-302

19. Bollinger A, Fagrell B (1990) Clinical capillaroscopy - a guide to its use in clinical research and practice. Hogrefe \& Huber Publishers, Lewiston

20. Fagrell B, Rosén L, Eriksson S-E (1994) Comparison between a new computerised and an analogue videophotometric, crosscorrelation technique for measuring capillary blood cell velocity in humans. Int J Microcirc Clin Exp 14: 133-138

21. Fagrell B, Fronek A, Intaglietta M (1977) A microscope television system for studying flow velocity in human skin capillaries. Am J Physiol 233 (2): H318-H321

22. Tooke JE, Östergren J, Fagrell B (1983) Synchronous assessment of human skin microcirculation by laser Doppler flowmetry and dynamic capillaroscopy. Int $\mathrm{J}$ Microcirc Clin Exp 2: 277-284

23. Fagrell B (1994) Problems using laser Doppler on the skin in clinical practice. Part 1. In: Belcaro G, Hoffman U, Bollinger A, Nicolaides A (eds) Laser Doppler Med-Orion, London, pp 49-54

24. Richardson D, Schwartz R (1984) Comparison of resting capillary flow dynamics in the finger and toe nailfolds. Microcirculation, Endothelium, and Lymphatics 1: 645-656

25. Östergren J (1984) Studies on skin capillary blood cell velocity by videophotometric capillaroscopy. Repro Print $\mathrm{AB}$, Stockholm

26. Jörneskog G, Fagrell B (1996) Discrepancy in skin capillary circulation between fingers and toes in patients with type 1 diabetes. Int J Microcirc 16: 313-319
27. Caspary L, Creutzig A, Alexander K (1988) Biological zero in laser Doppler fluxmetry. Int J Microcirc Clin Exp 7: 367-371

28. Faris I, Agerskov K, Henricksen O, Lassen NA, Parving HH (1982) Decreased distensibility of a passive vascular bed in diabetes mellitus: an indicator of microangiopathy? Diabetologia 23: 411-413

29. Rayman G, Malik RA, Metcalfe J, Sharma AK, Day JL (1989) Relationship between impaired skin microvascular responses to injury and abnormal capillary morphology in the feet of type 1 diabetics. Diabet Med 6: [suppl] 7 (Abstract)

30. Bayliss WM (1902) On the local reactions of the arterial wall to changes of internal pressure. J Physiol (Lond) 28: 220-231

31. Folkow B (1949) Intravascular pressure as a factor regulating the tone of the small vessels. Acta Physiol Scand 17: 289-310

32. Johnson PC, Burton KS, Henrich H, Henrich U (1976) Effect of occlusion duration on reactive hyperaemia in sartorius muscle capillaries. Am J Physiol 230 (3): 715-719

33. Patterson GC (1956) The role of intravascular pressure in the causation of reactive hyperaemia in the human forearm. Clin Sci 15: 17-25

34. Mullarkey CJ, Brownlee M (1994) Biochemical basis of microvascular disease. In: Pickup JC, Williams G (eds) Chronic complications of diabetes. Blackwell Scientific Publications, Oxford, pp 20-29

35. Williamson JR, Kilo C (1992) Basement membrane physiology and pathophysiology. In: Alberti KGMM, DeFronzo RA, Keen H, Zimmet P (eds) International textbook of diabetes mellitus. John Wiley, Chichester 2: 1245-1265

36. Raskin P, Pietri A, Unger R, Shannon WA Jr (1983) The effect of diabetic control on skeletal muscle capillary basement membrane width in patients with type 1 diabetes mellitus. New Engl J Med 309: 1546-1550

37. Furchgott RF (1983) Role of the endothelium in responses of vascular smooth muscle. Circ Res 1983; 53: 557-573

38. Johnson M, Harrison HE, Raftery AT, Elder JB (1979) Vascular prostacyclin may be reduced in diabetes in man. Lancet I: $325-326$

39. Silberbauer K, Schernthaner G, Sinzinger H, Piza-Katzer H, Winter M (1979) Decreased vascular prostacyclin in juvenile-onset diabetes. N Engl Med J 300: 366-367

40. Conrad MC (1971) Functional anatomy of the circulation to the lower extremities. Year Book Medical publishers Inc. Chicago

41. Watkins PJ, Edmonds ME (1983) Sympathetic nerve failure in diabetes. Diabetologia 25: 75-77

42. Williamson JR, Chang K, Frangos M, et al. (1993) Hyperglycemic pseudohypoxia and diabetic complications. Diabetes 42 : $801-813$ 